seem more satisfied with the semblance of 'stability' and with the rhetoric of democracy and development than with their delivery.

This article will contend that the eruption of violent conflict in the Ethiopian-Eritrean border area is neither unexpected nor the result of a real border dispute, and is due to (1) the particular history and relationship of the two insurgent movements turned national governments (EPLF and TPLF) in the two countries; (2) the nature and heritage of neo-patrimonial elite rule and the lack of democratic restructuring in the two countries; and (3) the economic problems of Eritrea as an independent state. These three elements will be briefly discussed after an overview of the current conflict.

Fighting

On 6 May 1998, Eritrean troops crossed the de facto western border between Eritrea and Ethiopia and occupied the village of Badme, followed by a larger effort on 12 May to establish themselves in the surrounding area. ${ }^{6}$ Local inhabitants were people who had counted themselves as Ethiopians (Tigrayans), because they had always paid taxes to Ethiopia and had been politically and judicially administered by Ethiopian authorities. ${ }^{7}$ However, over the past decade, several thousand people from Eritrea in search of farmland or alluvial gold had also settled in the area, and misunderstandings over the border had been occurring here and elsewhere. After the fighting in May, the area was placed under Eritrean rule. Most of the local people fled further south into Tigray.

In the subsequent weeks, fighting also erupted in three other border localities more to the east: Altena, Zalambessa, and Buré, south of the port city of Asseb. Eritrean forces made slight advances on all these fronts, but were prevented from moving further inland. In the skirmishes several thousand people, troops and civilians, are estimated to have been killed. In all, more than 130,000 people were displaced and lost their possessions. Local buildings, property and churches were allegedly destroyed and looted. After the fighting on the Badme front, the Eritrean airforce bombed the Tigrayan towns of Meqele and Adigrat (some 70 people were killed and hundreds wounded), while Ethiopia almost simultaneously bombed Asmara's airforce base (one person killed, a few dozen wounded). Eritrea's air strikes on civilian not military targets (residential areas, schools, hospitals, grain stores, factories) shocked and angered the Ethiopians. Since July there has been a US-brokered moratorium on air 6. See Rosalind Russell, 'Ethiopia says unprepared for Entrean invasion', Reuters dispatch, 14 June 1998.

7. The Eritreans had not clamed this area at independence in 1993, nor did they contest the census in the localties now claimed as Eritrean territory (Badme, Altena Zalambessa, Shiraro) are found in: Central Statistical Authortty, The 1994 Population and Housing Census for Ethiopia. Results for Tigray, Vol. I, pp. 11, 13 (CSA, Addis Ababa, 1995) trikes, while ground fighting has largely subsided since about the same time.

Economic effects and expulsions

The economic effects of the conflict were immediately felt: both countries cut air and road links, telephone lines and cross-border trade. In Eritrea prices for staple foods shot up. Eritrea held back all

goods in the port of Asseb destined for Ethiopia, to a value of tens of millions of dollars, and Ethiopia diverted all its shipping for Massawa and Asseb to Djibouti port, and threatened to block other ships from docking in the: Eritrean ports. ${ }^{8}$

In June this year, both countries also started to expel citizens of the enemy country', a process which led to incidents of intimidation, harassment, robbery and plunder, and worse. The Ethiopian government media, and also the country's independent press, have described serious abuse, repression, forceful expulsion, torture and killings of Ethiopians in Eritrea. Eritrea's government media soon followed suit and exposed humerous cases of unwarranted expulsion and serious maltreatment perpetrated against Eritreans in Ethiopia. Most of these stories are difficult to check as to numbers and the nature of the abuse, but accounts in the independent Ethiopian press (which allegedly relied on local correspondents and interviewed returning eye-witnesses) and in some

Eritrean reports are alarming. The Ethiopians have allowed international ebservers, such as the International Committee of the Red Cross, to visit detention camps and witness expulsions, while Eritrea has not yet. ${ }^{9}$ It must be emphasized that due to exaggerated reports and sometimes propaganda from both sides, the real story of the expulsions and the abuses will not be known for some time.

(1)

Mediation

Mediation efforts in this conflict have been intensive, with a string of Affican leaders-including Zimbabwe's Robert Mugabe, Djibouti's Hassan Gouled, Rwanda's Paul Kagame, and Kenya's Daniel arap Moi-passing by in both capitals. Several others, including presidents Mubarak of Egypt and Gadhafi of Libya, offered their good offices. But all in vain. Also the UN, US-Rwandan facilitators and the Organization of African Unity (OAU) have tried their best, but compromise proposals by especially the OAU (the most recent ones prepared during its meetings in Ouagadougou in early August) were rejected by Eritrea (because it was Ëvokng velled threats of retaliation from Entrean president Isayas Afeworq1: see his erview with The Trmes, 12 June 1998.

9. On 14 August, they gave permission for UN human rights investigators to examine cases of expulsions of Ethiopians from Eritrea. Eritrea is not a signatory of etther the Geneva Conventions or the African Charter on Human Rights and People's Rights. 
suggested by the OAU that Badme was administered by Ethiopia before 6 May), while Ethiopia restated its erstwhile position that negotiations on the border could only start after withdrawal of the Entrean military from its territory There is a war of words even on what happened on the ground? But it is fairly certain that Eritrean troops are now in an area where they were not present before 6 May 1998,10 and that they later also opened the fronts near Altena, Buré and Zalambessa. Meanwhile that there were small-scale incidents and possibly provocations from both sides seems clear enough, as these have frequently been discussed in meetings of the joint border commission during the past years.

But the OAU said in its statement of 1 August 1998, according to Reuters: "What happened in Badme between 6 and 12 May constitutes a: fundamental element of crises... The challenge is to find a solution to that particular problem.' This is the most diplomatic way of saying that Eritrea moved into the Badme area and kept it occupied. This fact is no longer disputed by anybody not even Eritrea, because they claimed subsequently that they '. . . only retook land that was already theirs' and could not retreat from it. ${ }^{11}$ A breakthrough in this situation of deadlock was therefore not achieved. In mid-August, an ominous silence had fallen upon the front lines. But the propaganda campaigns, the international mediation efforts and the military preparations went on.

What seems certain in this conflict is that the impact of the international community on its final outcome will be very limited. This also applies to the OAU, initially hailed by both sides as the best mediator. It cannot be otherwise in a conflict whose roots go back to the very specific history of tensions between the two insurgent movements, TPLF and EPLF, during the armed struggle in the 1970s and 1980s. This history, which is not taken into account by most outside observers, is the enduring frame of reference for political action of the leadership elites in Eritrea and Ethiopia. It is in these terms and aganst this background that these leaders will seek a solution. It should not be forgotten that these two movements, though influenced by revolutionary Marxist-socialist ideas, were strongly inward-looking, largely self-sufficient, and geared to the specific Ethiopian-Eritrean situation.

\section{Contesting the border}

The border between Ethiopia and Eritrea, after the de facto independence of Eritrea in May 1991, was that of the Italian colony of Eritrea, established in 1890, and confirmed in treaties in 1897 (after the Battle of Adwa), 1900 10 In an interview on Eritrean Television on 8 July 1998, President Isayas was reported to)
have sad 'Even if the sun doesn't nse, we will never withdraw from Badme', thereby. have said 'Even if the sun doesn't rise, we will never withdraw from Badme', thereby. and face adverse economic consequences if this was necessary, Reuters dispatch, 9 July 1998 . and face adverse economic consequences if this was necessary, Reuters dispatch, 9 July 1998.
11 . the Ethopian private paper Reporter, 22 June 1998, and BBC World News, 1 June
$1998,17.39$ GMT and 1902 between Italy and the Ethiopian emperor Minilik II. On the Whole, the line of this border was well-known and was generally respected except for limited areas where Italy continued to encroach, up to its full-scale invasion of Ethiopia in 1935. After her occupation, Italy rejected all agreed maps and treaties and imposed her own. Nevertheless, while detailed demarcations on the ground had not been made (partly because much of it was unnhabited at the time of the treaty-making, and ho necessity for it was seen), before 1935 it was usually clear on the basis of the treaty maps who was administered by which government and who Identified with what.

When Eritrea gained its de facto independence in 1991, the Italian colonial borders as agreed in the treaties of the beginning of this century Wrere taken as a point of departure, with the proviso that details would have to be decided upon. In the course of the current dispute, Eritrea, however, contended that a unilateral Italian map of 1934 should serve as the basis of the demarcation, but this seems to be contrary to the treaties and to international law, and has not been accepted by Ethiopia. In the present conflict, Italy even had the temerity to offer mediation on the basis of its colonial maps-an unhelpful if not arrogant gesture which found ne serious response from either side. ${ }^{12}$ In the post-1991 period, there were border crossings by people and militias of both countries, but disagreements had always been settled locally.

During the liberation struggle of EPLF and TPLF, there were some disputes on the exact border between the two countries to be, but this was seen as a minor point which they expected to solve later. They also thought that they, as insurgent movements, could not simply establish a new international border. In the past years an Eritrean-Ethiopian border commission worked on the issue, right up to the outbreak of hostilities on 6 May. ${ }^{13}$

- The conflict, then, is plagued by the heritage of Italian colonialism, to Which Eritrea as a state largely traces its identity as a separate territory and hation. ${ }^{14}$ Before the $1890 \mathrm{~s}$, Eritrea was known as the Bahr Negash area ind, although infiltrated by Italians since 1869 , could be considered as a part of the Ethopian highland polity. This held especially for the Tigrinya-speaking group (some 50 percent of the total) and for other ethnic roups like the Afar and Kunama, though less so for the pastoral nomadic Istamic peoples in the lowlands. During the liberation struggle in the 1970 s and 1980s, the Badme area was first occupied by the Eritrean

12. See Addis Tribune, 31 July 1998 vithout giving notice

4 See also C. Clapham, 'Boundary and terntory in the Horn of Africa', in P Nugent \& A I. Asiwaju eds., African Boundares. barners, condunts and opportuntzes (Pinter, London, 1996), p 242 
Liberation Front (ELF), a largely Muslim movement. When the ELF was forced out of Eritrea by the rival EPLF, who replaced it as the dominant liberation movement in the mid-1970s, the latter's ally, the TPLF, took it over with the understanding that details about the exact national borders were to be settled with the EPLF later.

\section{Backgrounds}

The border dispute is all about the politics of state survival. Eritrea as. a new independent state was always closely linked to the present EPRDF regime in Addis Ababa and was crucially assisted by the latter in political and economic terms. But eternal friendship between the two was not guaranteed. The fact is that the TPLF and the EPLF, which form the core of the present regimes in the two countries, were by no means unconditional allies in the insurgency against the regimes of Emperor Haile Sellassie and of Mengistu, but, as sectarian movements, had an inherently problematic relationship. Although they were condemned to support each other in the military struggle, there were crucial issues of conflict; rooted in the diverging social and political histories and ideologies of the two movements. ${ }^{15}$ These issues do not explain the current border conflict, but indicate some of the inherent tensions between the two regimes,

First, there were ideological differences on the struggle for 'national liberation and self-determination'. The TPLF, which ultimately opted for a take-over of the central state and not for Tigray independence (although this formula was in its first programme of 1976), recognized the old Stalinist clause on the right of nationalities, defined as ethno-linguistic groups, to 'national self-determination, up to and including secession'." The Eritreans, bound to their view of Eritrea as a territorial colony of Italy and later Ethiopia, did not. They claimed that the colonial experience: had forced an Eritrean identity over and above ethno-religious differences among its nine ethnic groups. The TPLF strove for a "voluntary union of the nationalities in Ethiopia' and inserted the right to secession in the new Ethiopian Constitution of 1995. Both policies are in a state of tension because 'nationalities' like the Afar, the Tigreans, the Saho and the Kunama straddle the border. This, coupled to problems arising from the " Muslim-Christian divide, has led to lingernng insecurity of the Eritrean leadership about the domestic political situation.

Second, the Fronts differed in other details of socialist theory and practice. While both coupled their armed struggle to social revolution in the countryside they controlled, there were differences in approach and in socialist policy. Some of these were typical Marxist squabbles, such 15 For a new and path-breaking study of the history of modern Entrea in relation to Ethiopia, see Tekeste Negash, Ertrea and Ethropra. the federal experence (Nordiska AfrikaInstitutet, Uppsala, 1997). For the political disagreements between the two Fronts, see sabout the 'social-imperralist' nature of the Soviet Union. Others were about the way of mobilizing the peasantry and about the re-organization of rural society. These factors had some impact as well on the nature of warfare with the Derg. The EPLF, after the initial phase of pure guerrilla Warfare, preferred more conventional combat with large-scale battles from fixed positions. The TLPF remained more dependent on surprise attacks, the high mobility of units, tactical retreats, etc, only choosing large-scale battle if they were sure they could win. ${ }^{16}$ These military notions had an impact on their relations with the population, and still have lingering effect.

Third, there was a history of unspecified territorial claims between the Fironts. As both guerrilla movements were dominated by Tigrinyaspeakers, the delineation of a border between Tigray and Eritrea was a delicate issue. Joint talks on this during the years of struggle did not yield agreements.

Fourth, there are also psychological factors, always underestimated. The impact of the colonial Italian administration (1890-1941) and the British mandate period (1941-1952) gave middle-class, politically active Eritreans a self-image of being more advanced than the 'backward Ethiopians'. This self-perception was remforced in the liberation war and is still very potent in the political arena. In recent years it led to Ethiopian stereotyping of Eritreans as arrogant towards Ethiopians (a result of recent political developments but at variance with reality when applied to the common people). In the case of the two Fronts this was stimulated by the EPLF being the senior in the partnership with TPLF during the years of armed struggle. The former had assisted in the organization and training of the younger TPLF, although the latter achieved its own strong identity. (The two Fronts completely broke off relations in the years 1985-1988.)

2. Fifth, Eritrea has an apparent need to contınuously assert itself politically in the region. It has conflicts with Yemen, Dibouti, Sudan, and now Ethiopia. The Eritrean leadership has repeatedly said it will not tolerate any government hostile to Eritrea.

In the post-1991 liberation period these problems have come together in the issue of the nature of political authority. Both regimes suffer from a political culture of autocratic rule where absolute power is cherished. One could argue that after the 1991 victory they seamlessly fitted into a model of neo-patrimonial politics. Neo-patrimonialism is seen here in a comparative sense and held to be a political model of (a) personalized, authoritarian rule, extended with strong bonds of personal loyalty, and (b) control and distribution of economic resources in a group constituted by 16. Negash, Entrea and Ethropia, Young, 'The Tigray and Eritrean People's Liberation Front' 
such personalized bonds. ${ }^{17}$ Power is thus a patrimony not democratically, or meritocratically, accessible to others.

There is insufficient space to elaborate on this, but the regimes in Ethiopia and Eritrea, despite their social-revolutionary credentials, do have such neo-patrimonial traits, which function to maintain elite rule and authority of a strictly organized dominant party. The two regimes came to power on a programme of liberation from autocracy, standing for the interests of the broad mass of the population, and for freer political and economic development. The realization of this programme has been incomplete. Both governments issued from tightly-knit elite groups with a tradition of authoritarian rule and (ethnic) group cohesion. As governments, they have shown indifference towards the spirit and the institutions of democracy, dialogue and impartial justice, in favour of political control and regime stability. They have a dominant (in the case of Eritrea, single) party political structure with no significant opportunities for opposition groupings to participate, and they rule with subservient parliaments that have no legal right of initiative. Both regimes have practised fairly authoritarian elite rule, to a significant extent geared to their own ethnie group. They govern without any strongly institutionalized rule of law Critics say their power seems ultimately still based on the gun and on tight control and regimentation of social life. This approach was successful in a guerrilla war against an extremely centralist and deeply repressive regime (Mengistu), ${ }^{18}$ but is not necessarily suitable to run a country in peace time. At the same time, the Ethiopian and Eritrean regimes seem unable to modify this approach, because of, first, structural and ideological limitations, and second, the stakes being so high, especially in Eritrea with its promising but weak economy, characterized by very low export yields. The adverse effects of such elite rule and of failed democratic institution= alization on domestic and regional stability will be felt in the coming years:

A third and more direct domain of tension is that of the economic problems of the new state of Eritrea. These result from its strong dependence on Ethiopia in most respects (food imports, export markets; raw materials, credits), which makes the country vulnerable. In 1997, the Ethiopian government tried to adjust its until then rather Eritrea-friendly economic policy.19 Many observers see this as the central reason for the timing of the conflict: by forcefully bringing up the border issue, the Eritrean government has put pressure on the Ethiopian leadership and tried to force it to return to a more Eritrea-favourable position by way of inducing the pro-Eritrea factions in the ruling EPRDF to assert

17. Cf. M. Bratton \& N van de Walle, Democratc Experments in Africa (Cambridge Universtry Press, Cambridge, 1997), p. 61f.

18. Cf. D. Pool, 'The Ertrean People's Liberation Front', in C. Clapham, ed., African

Guernllas (James Currey, Oxford, 1997), pp. 27-28.
19. For one economist's account, see Addurs Trbbune, 31 July 1998. themselves. ${ }^{20}$ It has also used its ports as a bargaining chip: port dues paid by land-locked Ethiopia were one of the most important sources of income for the Eritrean state. All this shows that, despite the promising beginnings and the healthy emphasis on its own resources, the economic viability of Eritrea is still very precarious and that in practice it is very much thed to Ethiopia.

* The economic tensions came to a height last year, when Eritrea introduced its own currency (the naqfa) after seven years of privileged use of the Ethiopian birr (because of the more favourable fiscal regime in Eritrea) and of the Ethiopian banking system providing generous loans. Contrary to expectations, Ethiopia then demanded all trans-border trade above 2000 birr to be conducted in hard currency, and not in birr or naqfa. The Eritreans were further angered when Ethiopia immediately issued new currency notes, thus declaring all birr still held by Eritrea, intended for use in purchasing Ethiopian goods and services from the Ethiopian market, where the weak naqfa would not be popular, as null and void, although Eritrea later got the chance to change all the old birr into new. Parity between birr and naqfa was also rejected by the Ethiopians (the rate just before the outbreak of hostilities was one birr=five naqfa). In addition, at the time of the currency change in November 1997, the

Eritrean banks had run into bad debts to the Commercial Bank of Ethiopia to the extent of 1.2 billion birr, which is probably now an irrecoverable loss for Ethiopia. ${ }^{21}$ Such problems, it is now claimed by observers critical of the Ethiopian government, were the result of an unclear and non-reciprocal policy, economically favouring Eritrea.

Redefinitions of boundary and national identity

The current conflict is the direct result of the unresolved and ambiguous political relationship between the two countries, and the two leaderships' policy of making deals without securing a broad national consensus or lểgally clear formulas. (Economic, military and security agreements are still not made public). The consequences can be serious.

It is clear that important changes will come about in the sphere of activity and the status of Eritreans in Ethiopia. This is already evident from the expulsions mentioned above. This status is an extremely complicated and sensitive point. An estimated 350,000 Eritreans live in Ethiopia. Many of them are recent immigrants and former military personnel who came in 1991, but most of them were born and bred there. They are now declared Eritrean because their parents were originally from Eritrea (then Ethiopia, or before 1941 the Italian Colony). Many of them are proud of their new 20. Asserted by L Santoro, 'At the root of an odd African war. money', Christzan Sctence Monitor, 22 June 1998.

21. See the Ethiopian independent weekly T'obbiya, 6 August 1998 
independent motherland Eritrea, but others are relatively indifferent: Also, some 60,000 Eritreans in Ethiopia voted in the 1993 Eritrean referendum for independence (an anomaly, because they were also Ethiopian citizens). Their de facto dual citizenship accorded them privileges compared to the average Ethiopian ctizen (e.g., advantages in: cross-border trading, getting credits, the right to bear arms) but this will now probably be revised. The Ethiopian government now claims, in a complete reversal of earlier policy, that many Eritreans are allegedly a. security risk, especially those that have served in the EPLF army (tens of thousands) and those who are (still) in high positions in Ethiopia (in government or in business). The impending changes have induced in security and fear among Eritreans in Ethiopia, 22 and have also led to many personal tragedies, e.g., sudden job loss without compensation; forced migration, the abandoning of children and the splitting up of mixed Ethiopian-Eritrean marriages because of the emergence of 'doubleloyalties' in the wake of this conflict.

The expulsions of Eritreans from Ethiopia are thus very controversial: ${ }^{23}$ many were dismissed for being 'agents of the Eritrean regime' giving financial support and inside intelligence information to their government (and the Ethiopian government has good records of that, because the Eritreans used to be close allies within Ethiopia). But hundreds of others have been expelled arbitrarily and see their lives, careers and education destroyed (e.g., many 'Eritrean' students at Addis Ababa University being' rounded up, interned or expelled, to the dismay of most of their Ethiopian friends). ${ }^{24}$ Most of those expelled had to leave their assets, which were frozen or given in legal custody to friends and others, and were limited in what they could take out of the country.

The position of Ethiopians in Eritrea has also been extremely precarious. In fact, massive expulsion of Ethiopians in Eritrea already started in 1991 and led to at least 50,000 people (traders, workers in the port of Asseb and in industry and services, Ethiopian army personnel and government administrators) being sent out without any of their possessions. Many thousands of them today still live in the streets of Addis Ababa in self-built shanties of plastic, stones and corrugated iron sheets, jobless and without government support. In fact, stories about the maltreatment, abuse and killings of Ethiopians in Eritrea at that time were suppressed for seven years but are now appearing even in the Ethiopian 22. The highly symbolic execution on 2 June 1998 of Jemal Yassin Mohamed, an Eritrean
convicted last year for klling the popular TPLF-general Hayalom Araya, also contributed to 23. According to the Ethopian government, more than 10,000 Entreans had been expelled
this. by mid-August 1998 .

24. See T'obbiya of 6 August 1998, protestng aganst this Also the independent paper Mebruk, on 25 June 1998, warned against 'revenge' on Entreans in general. government press. The new wave of expulsions seems to be even more iramatic and violent. 25

In the wake of this conflict, the two governments will probably redefine the status and nationality of the Ethiopians and Eritreans in the respective countries in a legally clearer manner. In the meantime, however, contacts and the mobility of people between the two countries will be severely estricted and mutual suspicion will increase.

Political tension in the post-1991 era

Eritrea and Ethiopia have regimes that issued from successful MarxistLeninist insurgent movements that were of military orientation and marked by strict central control and elite cohesion and discipline. They were good at mobilizing their people and revolutionizing life in the countryside, but not in developing a pluralist system on the national level to accommodate differences of opinion, democratic decision-making and consensus thinking. Political structures are still top-down, 'democratic-centralist', and monolithic. Most senior figures in both countries think it cannot be otherwise in the light of local political culture and socio-economic conditions.

2. The experience of the past seven years, a period that did yield many new opportunities, has been that, on the general level, the political culture of autocracy and of fear and respect for authority that existed in these countries has been maintained. Second, on the more immediate political level there is still a fundamental lack of institutionalized democracy in both countries. Democracy not only in the sense of free and fair elections, unencumbered political party life, a free press, free civil society, national debate with opposition groups, or fair justice and rule of law, but also in the public mentality of the elites to run a country with a modicum of tolerance, openness, fairness and political goodwill. Authoritarianism and neopatrimonialism thus continue to mark the structures of political and public ife. Notwithstanding gains made relative to the Marxist-communist dictatorship of Mengistu, crucial national issues have been decided upon without the people having a real say. Examples are: the political-electoral system, the re-division of the country into ethnic regions, the exclusion of epposition groups to play a role, the political co-optation of civil society arganizations like the CETU trade union and the ETA teachers' union, the hon-transparent privatization policy, or the unconditional split-off of

55. One of the worst reported (first in the Ethopian independent weekly Minnllk, 18 July 1998) was the detention of Ethopian workers in Asseb in a metal contanner which was then placed in the blazing sun At the end of the day, almost all the sixty victms had died of heat and asphyxiation. Although eyewitness accounts exist (see the Ethiopia-Eritrea Conflict Page', website Http://www geocittes.com/Eureka/Park/5875) the incident has not been confirmed from independent sources. Incidentally, donor-country or UN mission report of reasons. 
Eritrea, whereby nothing was negotiated except a 'free access to the ports on the Red Sea' (as it now appears, without guarantee). ${ }^{26}$ This general lack of debate and consensus on issues of national interest and the lack of sufficiently democratic institutions have been enduring sources of tension within Ethiopia, and indeed can be partly held responsible for the emergence of the present quarrel with Eritrea.

Future relations

The conflict has sealed the irreversible secession of Eritrea froth Ethiopia. Ethiopians in all walks of life, while deploring this fact in itself; do not want Eritrea back, but they want to press it to stand on its own feet (although 'irredentist' Ethiopians think this the chance to get back Eritrea altogether, but it is unclear for what benefit and for whom).

However, what is most regrettable is that the antagonism and, in many cases, the hatred that has been generated by policies and rhetoric of the two regimes is now sinking down to the level of daily life and inter-personall relationships. This is a new and very significant fact resulting from the present border conflict. Previously, any deep-rooted antipathy between the common people was prevented by religious, cultural and historical similarities, intermarriage and integrated economic activities. The fact that people now start to deny these elements, or choose to emphasize that which differentiates them, is a dubious 'achievement' of the policy of the two regimes. If this was their aim, then they have succeeded: if the present regime in Asmara holds, Eritrea will not return, not even in a confederation, to Ethiopia in the foreseeable future.

Internal changes

The conflict with Eritrea has shown that the EPRDF regime in Ethiopia has to broaden its base of support in the country. Opposition forces had already insisted on this for seven years and had extended this demand to the redressing of the relation of Ethiopia with Eritrea, but only now are their views being appropriated by the regime. One also sees unpreeedented criticism by EPRDF and government leaders of the Eritrean regime, of a type already made by opposition figures and the independent press in the years before. 27

The process of gaining broader acceptance is by no means easy for the Ethiopian government. So far, there has been a spontaneous process from below, with Ethiopians everywhere expressing support for the defence of the territorial integrity of the country. The federal leadership is, so to 26. E.g., the referendum on the independence of Entrea-until then part of Ethropia-Wâs held without any Ethiopian role in the matter. It was unconditionally granted by the thet Transitional Government of Ethiopia led by the EPRDF.

列 interviewed by Rosalind Russell, Reuters, 8 June 1998. speak, 'being reclaimed' by the old tradition of Ethiopian nationhood, but What this will mean in political-institutional terms is uncertain.

For Eritrea, changes might be forthcoming in the leadership and also in its policies of achieving more democratic structures. It can show some economic recovery since 1991, but political liberalization has lagged behind. Some have asserted that despite the war of independence being over since 1991, the country is still run like an army camp. Perhaps a move away from an authoritarian and parochial leadership style might be demanded by both the public and elements of the army. If the government does not deliver, more discontent may emerge, especially when the Eritrean public gets more access to independent information.$$
\text { Trition }
$$$$
\text { Prospects }
$$

- After the Eritrean bombing of a school and a hospital in June, some veople in Tigray's capital town of Meqele were heard to say: 'We don't understand any more: we have been told by the government all the time in the past years that our worst enemies were "the Amhara" and so on, and that our best friends were the Eritreans. Now we find that these best friends are bombing our people here in Tigray, in Meqele, in Adigrat, While the Amhara and the others come to our rescue and to defend our country ...'28

This may not be entirely correct, but such thoughts prefigure the changes to come in the relations between Eritrea and Ethiopia in the wake of the border conflict. National identity in Ethiopia is resurgent and the EPRDF leadership is forced to deal with the call for the defence of the nation's boundaries. It will, however, try to do this without endangering its hegemony, and thus with minimal concessions to opposition forces and the Ethiopian public at large. As Mengistu did during and after the war against Somalia in 1977-78, cooptation and neutralisation will be the preferred strategy. Further democratization of the Ethiopian polity thus remains precarious.

Eritrea has taken a domestic and international risk in escalating the tensions on the border and escalating armed conflict in the disputed Badme area. In this border crossing also, the pattern of Eritrea's conflicts with Yemen and Djibouti is visible: first create military facts on the ground and then call for neutral, third-party, unconditional face-to-face negotiations. ${ }^{29}$ But it is not certain that the outcome will be similar. The decision to move in with full force could have been a miscalculation by the Eritrean leâdership on the Ethiopian resolve and capacity to defend the borders. But more likely it was a conscious move to force the Ethiopian leadership to modify its new policies towards Eritrea, or to induce changes in the 28. Personal communications from travellers returning from Meqele met by the author, tuly 1998

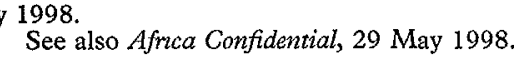


leadership alignment within the TPLF/EPRDF. In the process, Eritrea can also draw attention away from economic difficulties and from internal dissent (Afar and Benı Amer areas; ${ }^{30}$ grumblings about the lack of progress in establishing a democratic political system), although puzzlement will always remain as to the precise reasons why violence was used when surely. a more assertive political offensive might also have worked. Eritrea may here overestimate its military strength and economic stamina. It has, of course, a good army of highly motivated and experienced fighters, but so have the Ethiopians (i.e. of the TPLF, the core of the ruling EPRDF); Furthermore, it should not be forgotten that although in the late 1970s the TPLF grew in strength to a large extent under the wing of the EPLF, the decisive blow to the Derg armies of Mengistu Haile Mariam in 1989 91 (in so far as these did not crumble of their own in the last years of the war), was inflicted by the TPLF forces.

Faced with the Ethiopian potential, especially if the country emphasizes national unity again, Eritrea will thus have to appeal to other countries or donors to remforce its diplomatic position, economic prospects and military capacity. They will include notably Middle Eastern and Islamic. countries with an interest in the Red Sea area. There was already talk in July this year of Eritrea planning to join the Arab League, a supreme irony for a country where more than 50 percent of the population is Orthodox Christian, is not ethnically Arab, and where Arabic (though an official language and used by Muslim middle-class elites) is the indigenous language only of the 6,000-strong Rashaida people. ${ }^{31}$ Such a move might probably also run into some resistance among the Tigrinya-speaking population.

The short-term success of Eritrea's offensive has been to put the issue of Ethiopian-Eritrean boundaries/relations on the agenda of regional (Ethiopian-Eritrean relations, Intergovernmental Authority on Drought: and Development) and international politics (OAU, UN, donor-" countries). Whether it will ultimately lead to lasting success is another matter. Eritrea's actions have met with surprise and scepticism in most of the world press and among donor-countries. Ethiopia has, in the opinion of most observers, shown a more restrained approach to the issues at hand, and has de-escalated the military situation. A level-headed analysis would probably also show that the legal case of Ethiopia is somewhat stronger than the Eritrean one. But for a peaceful resolution, both sides have to meet half-way and to discuss the fundamentals of their relationship in a wider context.

30. The Ethopran government clamms that several thousand Eritrean Afar have fled to Ethiopıa Abdallah Gabber, a close political advisor to President Isayas Afeworq1, sadd in an interview with the United Arab Emirates' newspaper Al Khaleg (2 July 1998) that Entrea would eventually join the Arab League
The coming months will probably see a continuation of diplomatic efforts by the OAU, the UN and some donor-country ambassadors to break the dead-lock marked by Eritrea's refusal to accept the abovementioned international peace initiatives, and by Ethiopia's refusal to talk before the invaded territory is vacated. A steady military build-up on both sides will continue as well..$^{32}$ If the diplomatic effort meets with further resistance on both sides, and if the leadership in both countries cannot break lose from its inherited siege mentality and power arrogance, then a protracted front-line war, together with air raids and sabotage actions, is likely (perhaps starting from November-December, in the dry season) The decision to start such a war will again be partly dependent on the degree to which the pro-Eritrean element is able to maintain itself within Ethiopia's leadership. The outcome of further armed confrontation is by no means certain. Ethiopia has more equipment and manpower (though many new untrained recruits), and more economic resources to sustain a War, but Eritrea has a better army organization, more experienced fighters ând better and newer military hardware, except for its air force.

The general results of war are of course predictable, apart from tragic loss of life (a) severe economic damage, less foreign investment and genera subversion of promising socio-economic development efforts initiated in both countries, (b) a weakening of their position in the region (e.g. vis-à-vis Sudan, Egypt, and the Somalis), and (c) more internal dissent, instability, and probably increased state repression in both countries. The loser in this conflict will probably face serious political difficulties, even regime change. But in this conflict the common people will again be the biggest losers, victims of 'new leaders' who have lacked responsibility and democratic spirit, all too often uncritically supported by world powers not bothered by their own blissful ignorance of the intricacies of local history. Again, political history in Northeast Africa makes a full circle.

32. Entrea, in fact, already had started to call up ex-combatants on late 1997 See Economist Intelligence Unt, Entrea-Somalia-Djzboun. Country profile 1997-98 (London, 1997), p. 7 . 